\title{
Listeria monocytogenes Survival on Peaches and Nectarines under Conditions Simulating Commercial Stone-Fruit Packinghouse Operations
}

\author{
Deepa Kuttappan ${ }^{1}$, Muhammed S. Muyyarikkandy ${ }^{1,2}$, Elza Mathew ${ }^{1,3}$ and Mary Anne Amalaradjou $1, *$ (i) \\ 1 Department of Animal Science, University of Connecticut, Storrs, CT 06269, USA; \\ deepa.kuttappan@uconn.edu (D.K.); mmuyyar@ncsu.edu (M.S.M.); elza.mathew@umassmed.edu (E.M.) \\ 2 Department of Pathobiology and Population Health, College of Veterinary Medicine, North Carolina State \\ University, Raleigh, NC 27607, USA \\ 3 Department of Neurological Surgery, University of Massachusetts Medical School, Worcester, MA 01605, USA \\ * Correspondence: mary_anne.amalaradjou@uconn.edu; Tel.: +1-860-486-6620; Fax: +1-860-486-4375
}

\section{check for}

updates

Citation: Kuttappan, D.;

Muyyarikkandy, M.S.; Mathew, E.;

Amalaradjou, M.A. Listeria

monocytogenes Survival on Peaches

and Nectarines under Conditions

Simulating Commercial Stone-Fruit

Packinghouse Operations. Int. J.

Environ. Res. Public Health 2021, 18,

9174. https://doi.org/10.3390/

ijerph18179174

Academic Editor: Paul B. Tchounwou

Received: 9 August 2021

Accepted: 27 August 2021

Published: 31 August 2021

Publisher's Note: MDPI stays neutral with regard to jurisdictional claims in published maps and institutional affiliations.

Copyright: (c) 2021 by the authors. Licensee MDPI, Basel, Switzerland. This article is an open access article distributed under the terms and conditions of the Creative Commons Attribution (CC BY) license (https:/ / creativecommons.org/licenses/by/ $4.0 /)$.

\begin{abstract}
Recent recalls of stone fruit due to potential Listeria contamination and associated foodborne outbreaks highlight the risk for pathogen transmission through stone-fruit consumption. Particularly, surface contamination of fruits increases the risk for cross-contamination of produce during processing and storage. This highlights the need for quality control in stone fruits intended for consumption. To develop effective food safety practices, it is essential to determine the critical factors during stone-fruit processing that influence Listeria survival. Therefore, this study evaluated the ability of Listeria to survive on peaches and nectarines under simulated stone-fruit loading and staging, waxing and fungicide application and storage conditions. The results of our study indicate that current stone-fruit handling conditions do not favor Listeria growth. However, once fruit is contaminated, Listeria can survive on the fruit surface in significant numbers under current processing conditions. Therefore, there is a need to develop and implement preventive controls at the stone-fruit packinghouse to prevent Listeria contamination and deter pathogen persistence.
\end{abstract}

Keywords: Listeria monocytogenes; survival; stone fruits; packinghouse operations

\section{Introduction}

With increasing consumer awareness and demand for maintaining a healthier lifestyle, the consumption of fresh fruits and vegetables has increased over the last few decades [1]. However, the increased dietary incorporation of fresh produce has been linked to an increase in the incidence of produce-related foodborne outbreaks [2-4]. Human pathogens associated with produce include Salmonella, E. coli O157, Listeria monocytogenes, Bacillus cereus, Aeromonas and Shigella spp., Norovirus, Hepatitis A and Cyclospora [3,5]. Of these, Salmonella, E. coli O157:H7 and L. monocytogenes are the leading bacterial causes of produce-related foodborne illnesses $[3,6]$. Although primarily associated with dairy and RTE foods, Listeria has been increasingly implicated in different produce outbreaks and recalls including butternut squash, cauliflower, zucchini, broccoli, tomatoes, snap peas, cantaloupes, lettuce, sprouts and stone fruits [1,7-12].

Stone fruit, including peaches, nectarines, plums and pluots are generally considered as low risk fruit for foodborne illnesses [13]. However, in 2014, detection of Listeria led to a national recall of stone fruits. Furthermore, this recall was associated with a multistate outbreak that resulted in one fatality $[10,14,15]$. This first reported link between human listeriosis and stone fruit highlights a potentially new food vehicle in the transmission of Listeria monocytogenes. In addition, this outbreak also demonstrates the pathogen's ability to persist and survive on stone fruits through the handling, storage and transportation chain. Pathogen presence on the fruit's surface indicates that inadequate hygienic conditions were 
employed during harvesting, processing and/or transportation. This emphasizes the need for quality control in stone fruits intended for consumption.

The contamination of stone fruit can occur at any point along the production continuum. In the pre-harvest environment, fruit can get contaminated from contact with soil, water and animal manure $[13,16,17]$. In this regard, L. monocytogenes has been isolated from soil, waterways and vegetation, where it exists as a saprophyte [18-22]. Besides these sources, Listeria is known to be associated with the gut microflora of domestic and wild animals and shed in feces [23,24]. Therefore, use of improperly composted manure, wildlife access to the orchard and animal rearing adjoining the produce field can act as source of contamination to the stone fruit $[13,25-27]$. Once harvested, fruit can get contaminated during processing and transportation from food-contact surfaces, including equipment and handlers $[26,28,29]$. Moreover, given that fruit are consumed as raw or minimally processed foods, pathogen control on produce becomes more challenging. Further, heightened consumer demand for fresh produce has also led to the handling of large quantities of produce which are obtained from different producers, resulting in the pooling of raw products and extensive handling by several types of equipment and individuals. These factors further increase the risk for cross-contamination of produce during processing and storage $[16,30]$. Therefore, incorporation of good management practices in the post-harvest environment is critical to promoting produce safety [31].

In the post-harvest setting, survival of L. monocytogenes on produce is primarily influenced by environmental parameters, including temperature and relative humidity encountered in the packinghouse and during distribution [8,15,32-36]. Besides fruit handling and storage conditions, fruit waxing and fungicide treatments are frequently employed in stone-fruit packinghouses [37]. As with temperature and $\mathrm{RH}$, application of wax and fungicide can influence pathogen persistence and contamination on produce [32,38-43]. Another important factor that influences pathogen survival is the produce type [44]. Each produce type has a unique combination of compositional and physical characteristics that require specific growth conditions, harvesting protocols, processing practices and storage conditions [38]. So best management practices and preventive controls are highly producespecific. Therefore, to develop effective food safety practices, it is essential that each produce is evaluated appropriately under conditions that are applicable to its processing and storage. Hence, the objective of this study was to determine the influence of stone-fruit handling, processing and storage conditions on Listeria survival on peaches and nectarines. Ambient conditions (temperature and $\mathrm{RH}$ ), length of storage, fruit finish and fungicides used in the study are based on discussions with the California Fresh Fruit Association and adapted from the food safety guidelines for fresh whole stone fruit produced in California's San Joaquin valley [37] (Table 1).

Table 1. Stone-fruit handling, processing and storage conditions at a commercial packinghouse.

\begin{tabular}{cccc}
\hline Stage & Holding Temperature $\left.{ }^{\circ} \mathrm{C}\right)$ & Relative Humidity (\%) & Holding/Storage Time \\
\hline Unloading and staging & & & $40-50$ \\
Warm season & $28-30$ & $40-50$ & $1-18 \mathrm{~h}$ \\
Cool season & $18-20$ & & $1-18 \mathrm{~h}$ \\
\hline $\begin{array}{c}\text { Fruit finish and fungicide application }{ }^{*} \\
\text { Warm season }\end{array}$ & $28-30$ & $40-50$ & $1-6 \mathrm{~h}$ \\
Cool season & $18-20$ & $40-50$ & $1-6 \mathrm{~h}$ \\
\hline Refrigerated storage & $1-2$ & $85-95$ & $2-28 \mathrm{~d}$ \\
\hline
\end{tabular}

${ }^{\ddagger}$ Fruit finish/fungicide combinations used include mineral-oil- or vegetable-oil-based fruit finish containing fungicides fludioxonil or propiconazole.

Experimental conditions used in the study are adapted from the food safety guidelines for fresh whole stone fruit produced in California's San Joaquin valley [37] and based on discussions with the California Fresh Fruit Association. 


\section{Materials and Methods}

\subsection{Peaches and Nectarines}

Unripened, unwaxed fruits (yellow flesh peaches—var. Autumn Flame and nectarinesvar. August Fire) were procured immediately after harvest from Prima ${ }^{\circledR}$ Wawona, Reedley, CA, USA. Upon receipt, fruits were visually inspected for defects (bruises, moldy growth and breaks in peel), and any defective fruit was discarded. All fruits were maintained at 4 ${ }^{\circ} \mathrm{C}$, with $90 \%$ humidity, until use. A day before the experiment, the required number of fruits was transferred to room temperature $\left(20\right.$ or $\left.30^{\circ} \mathrm{C}\right)$ for tempering prior to use $[45,46]$.

\subsection{Bacterial Cultures and Inoculum Preparation}

A cocktail of L. monocytogenes isolates consisting of produce isolates (LM1, LM2, LM3apple isolates) and human isolates (Scott A, LM 19115) was used for the study. Each isolate was cultured separately in $10 \mathrm{~mL}$ of sterile brain heart infusion broth (BHI) and Nalidixic acid (NA; $50 \mu \mathrm{g} / \mathrm{mL}$ ) at $37^{\circ} \mathrm{C}$ for $24 \mathrm{~h}$ with agitation (100 rpm). Cultures were then transferred for two consecutive 24-h periods onto brain/heart infusion agar plates containing NA (BHIN) to produce a bacterial lawn. To prepare the inoculum, growth from the bacterial lawn was transferred to $0.1 \%$ buffered peptone water (BPW) to an absorbance of $0.2 \%$ [47]. The approximate bacterial count in each culture was determined spectrophotometrically. Equal portions from each of the five isolates were combined to make the pathogen cocktail. The bacterial population in the Listeria cocktail was determined by plating $0.1 \mathrm{~mL}$ portions of appropriate dilutions on modified Oxford media with NA (MOXN; [48]), followed by incubation at $37^{\circ} \mathrm{C}$ for $48 \mathrm{~h}$ [20]. Appropriate dilutions of the five-strain mixture in buffered peptone water (BPW) was used to obtain the desired level of inoculum. A high inoculum level (5 log CFU/fruit) was used to enable measurement of several $\log$ reductions in pathogens counts during the study [49]. Additionally, this study also incorporated a low level of inoculum (3 log CFU / fruit) in order to simulate low levels of pathogen contamination that are likely to occur under normal processing, storage and distribution conditions [50].

\subsection{Fruit Inoculation}

Fruits were individually spot-inoculated with the bacterial cocktail (7 or $5 \log \mathrm{CFU} /$ fruit) by placing $50 \mu \mathrm{L}$ of the inoculum around the stem end. In order to prevent the inoculum from running off the side of the fruit, the inoculum was applied in small approximately equal volumes to 10 different locations [8,46,51]. After inoculation, fruits were held for $24 \mathrm{~h}$ at room temperature in a biosafety hood for the inoculum to dry. Staggered inoculation of the fruits was performed to maintain consistent drying time for all fruits [52]. Before each experiment, 15 fruits were sampled immediately following and after drying ( $24 \mathrm{~h}$ post-inoculation) to determine pathogen load and inoculum uniformity on the fruits $[46,53]$.

\subsection{Survival of Listeria on Peaches and Nectarines under Simulated Fruit Handling, Waxing and} Storage Conditions

2.4.1. Stone-Fruit Unloading and Staging Conditions at the Packinghouse (Temperature-18-20 or $28-30^{\circ} \mathrm{C}$ (Ambient Cool and Warm Season Temperature), RH- $40-50 \%$ (Ambient Humidity) and Holding Time- 1 to $18 \mathrm{~h}$ )

This objective investigated the effect of stone-fruit handling at ambient temperatures and humidity as encountered during the staging and unloading of fruit at the packing facility. Following Listeria inoculation and drying, stone fruits were placed in unsealed sterile polycarbonate containers (8-3/4 in. $\times 8-5 / 16$ in. $\times 8-3 / 4$ in.; Fisher Scientific, Waltham, MA, USA $)$ and stored at $18-20\left(19 \pm 1{ }^{\circ} \mathrm{C}\right)$ or $28-30^{\circ} \mathrm{C}\left(29 \pm 1^{\circ} \mathrm{C}\right.$; ambient cool and warm season temperature), $\mathrm{RH} 40-50 \%$ ( $45 \pm 5 \%$; ambient humidity), for a time period of 1 to $18 \mathrm{~h}$ to simulate stone-fruit handling during transportation to and staging at the packing facility (Table 1). Relative humidity was monitored throughout the experiment, using a digital humidity/temperature/dew point meter (Traceable ${ }^{\mathrm{TM}}$, Fisher Scientific, Hampton, $\mathrm{NH}, \mathrm{USA})$. At designated times during the storage $(0,2,6,12$ and $18 \mathrm{~h})$, fruits were sampled 
for microbiological analysis, and the entire experiment was repeated three times. A similar experimental set up was used to evaluate Listeria survival on nectarines.

2.4.2. Fruit Waxing (Mineral-Oil- and Vegetable-Oil-Based Fruit Finish) and Fungicide Application (Fludioxonil and Propiconazole) at the Stone Fruits Packing Facility (Temperature-18-20 or $28-30^{\circ} \mathrm{C}$ (Ambient Cool and Warm Season Temperature), RH-40-50\% (Ambient Humidity) and Holding Time-1 to $6 \mathrm{~h}$ )

Peaches/nectarines were inoculated as previously described and used to investigate the effect of mineral-oil-based (PrimaFresh ${ }^{\circledR} 220$ ) and vegetable-oil-based (PrimaFresh ${ }^{\circledR} 55 \mathrm{EU}$ ) fruit finish containing fungicides (fludioxonil (PacRite ${ }^{\circledR}$ FDL) or propiconazole (Mentor $\left.{ }^{\circledR}\right)$ ) on Listeria survival. The fruit finish and fungicides were kindly provided by Pace International. The fungicide/fruit finish formulations were prepared according to manufacturer's instructions prior to application. Inoculated fruits were sprayed with one of four different wax/fungicide combinations, using a gravity-feed dual action air-nozzle sprayer at $28-30{ }^{\circ} \mathrm{C}\left(29 \pm 1{ }^{\circ} \mathrm{C}\right)$ or $18-20{ }^{\circ} \mathrm{C}\left(19 \pm 1^{\circ} \mathrm{C}\right.$; ambient warm and cool season temperature $)$ and $40-50 \%$ RH ( $45 \pm 5 \%$; ambient humidity; Table 1$)$. The formulations included mineral oil + fludioxonil (MF), mineral oil + propiconazole (MP), vegetable oil + fludioxonil (VF) and vegetable oil + propiconazole (VP). Each fruit was sprayed with one pull each to the stem and calyx ends and three pulls to coat the rest of the fruit surface. Following waxing, a subset of fruits was sampled to ascertain pathogen load prior to storage. Then, fruits were packed in sterile boxes to simulate packinghouse practices and held under ambient warm and cool conditions as described above for up to $6 \mathrm{~h}$. Surviving Listeria population on peaches was enumerated at different times during fruit holding. Listeria survival on nectarines was performed as described above.

2.4.3. Refrigerated Storage of Waxed Fruit at the Packinghouse (Temperature- $-1-2{ }^{\circ} \mathrm{C}, \mathrm{RH}$ $85-95 \%$ and Storage Time- 3 to 4 weeks)

Following waxing, peaches and nectarines are hand-placed into the final containers, and these boxes are then cooled to $1-2{ }^{\circ} \mathrm{C}$ and placed in cold storage prior to being shipped to market in refrigerated trailers. Therefore, to investigate the effect of cooling and storage conditions on Listeria survival, peaches/nectarines inoculated with $7 \log \mathrm{CFU} / \mathrm{mL}$ and $5 \log$ CFU/mL of Listeria cocktail were allowed to dry. The four fungicide fruit-finish combinations were prepared and sprayed under warm ambient conditions, packed and held for $6 \mathrm{~h}$, as per objective 2. Packed fruit were then stored at $1-2^{\circ} \mathrm{C}\left(1.0 \pm 0.5^{\circ} \mathrm{C}\right)$ and $\mathrm{RH}$ of $85-95 \%(90 \pm 5 \%)$ for four weeks (Table 1) to simulate fruit storage at the packinghouse. Surviving Listeria population on fruits were enumerated during the four-week storage period $(0,1,5,7,14,21$ and 28 days). Similar experimental set up was employed to enumerate Listeria populations on nectarines

\subsection{Microbiological Analyses}

At each sampling time, stone fruits $(n=4)$ were individually transferred to sterile stomacher bags containing $100 \mathrm{~mL}$ of BPW. Each fruit was hand-rubbed for $2 \mathrm{~min}$, and the BPW was analyzed for Listeria population and/or presence (enrichment). Briefly, BPW from the stomacher bags containing peaches or nectarines was serially diluted in BPW and duplicate $0.1 \mathrm{~mL}$ aliquots of the appropriate dilutions were surface plated on MOXN followed by incubation at $37^{\circ} \mathrm{C}$ for $48 \mathrm{~h}$ [20,54]. In addition to enumeration, BPW samples were enriched in Listeria enrichment broth UVM at $35^{\circ} \mathrm{C}$ for $24 \mathrm{~h}$. A $1 \mathrm{~mL}$ aliquot of the enriched UVM culture was then added to $9 \mathrm{~mL}$ of Fraser broth and incubated at $35^{\circ} \mathrm{C}$ for $24 \mathrm{~h}$. When counts for the respective samples were negative by direct plating, enrichment broths were streaked on MOXN and incubated at $37^{\circ} \mathrm{C}$ for $48 \mathrm{~h}$. Presumptive colonies isolated from MOXN plates were confirmed as Listeria monocytogenes, using the Singlepath ${ }^{\circledR}$ L'mono agglutination assay. 


\subsection{Statistical Analysis}

Four fruits were sampled at each sampling time, and three independent trials were conducted. Pooled samples $(n=12$ fruit/temperature/time point/variety under each experiment) were averaged, and the data were analyzed by using the mixed procedure of SAS ver. 9.2. Differences among the means were detected at $p<0.05$, using the Fisher's least significance difference test with appropriate corrections for multiple comparisons. Independent experiments were conducted to determine the effect of stone-fruit packinghouse conditions and practices on Listeria survival on peaches (var. Autumn Flame) and nectarines (August Fire).

\section{Results}

The results of our study did not demonstrate any statistically significant difference $(p>0.05)$ in the survival of Listeria on yellow-flesh peaches (var. Autumn Flame) and nectarines (var. August Fire) under simulated stone-fruit packinghouse conditions. Hence, only data for peaches are presented here.

\subsection{Survival of Listeria on Peaches under Simulated Packinghouse Conditions}

Approximately $6.60 \pm 0.03$ and $5.46 \pm 0.05 \log$ CFU of Listeria was recovered from the peaches inoculated with high and low inoculum levels, respectively, immediately following inoculation. Following the $24 \mathrm{~h}$ inoculum drying period, approximately $5.15 \pm 0.06$ and $3.25 \pm 0.05 \log$ CFU of the pathogen was recovered from the peaches at both inoculation levels. Similar results were obtained with nectarines. These results reveal that Listeria can survive in significant numbers on peaches and nectarines during the extended drying period. This surviving population would be representative of bacterial cells that can withstand desiccation on the fruit surface $[46,55]$. Hence, for all objectives, fruits were dried for $24 \mathrm{~h}$ following surface inoculation.

\subsection{Effect of Fruit Unloading and Staging Conditions on Listeria Survival on Stone Fruits}

Following harvest, fruits are transferred to the packinghouse. At the packinghouse, stone fruits are either left in the transport trucks for unloading or are unloaded and staged in an unloading area. Fruits can be staged for 1-18 $\mathrm{h}$ before they are dumped into the packing line. Therefore, to simulate this initial fruit holding conditions, inoculated fruit were held at either $28-30{ }^{\circ} \mathrm{C}\left(29 \pm 1{ }^{\circ} \mathrm{C}\right)$ or $18-20^{\circ} \mathrm{C}\left(19 \pm 1{ }^{\circ} \mathrm{C}\right)$ and $\mathrm{RH} 40-50 \%(45 \pm 5 \%)$ for $18 \mathrm{~h}$. As can be seen from Figure 1, survival of Listeria on peaches was not significantly affected by simulated stone-fruit unloading and staging conditions $(p>0.05)$. For instance, under warm ambient conditions, approximately $5.46 \pm 0.05$ and $5.71 \pm 0.22$ and $3.75 \pm 0.12$ and $3.85 \pm 0.05 \log$ CFU of the pathogen was recovered from fruit sampled at 0 and $18 \mathrm{~h}$ of the study under high and low pathogen inoculation levels, respectively (Figure 1). Under cool ambient temperatures, no significant change in Listeria population was observed throughout the study with $\sim 5.66 \pm 0.07$ and $3.83 \pm 0.04 \log$ CFU of Listeria recovered from the peaches at $18 \mathrm{~h}$ at both inoculation levels, respectively (Figure 1). Although an increase in pathogen populations was observed at $18 \mathrm{~h}$ of storage, these results were not found to significantly different from Listeria counts at $0 \mathrm{~h}$ (Figure 1). Similar results were obtained with experiments performed on nectarines. Overall, irrespective of the ambient conditions and inoculum load, Listeria was able to survive equally well on peaches and nectarines. Further, although the simulated fruit unloading and staging conditions did not deter Listeria survival, they also did not favor any significant increase in pathogen population. 


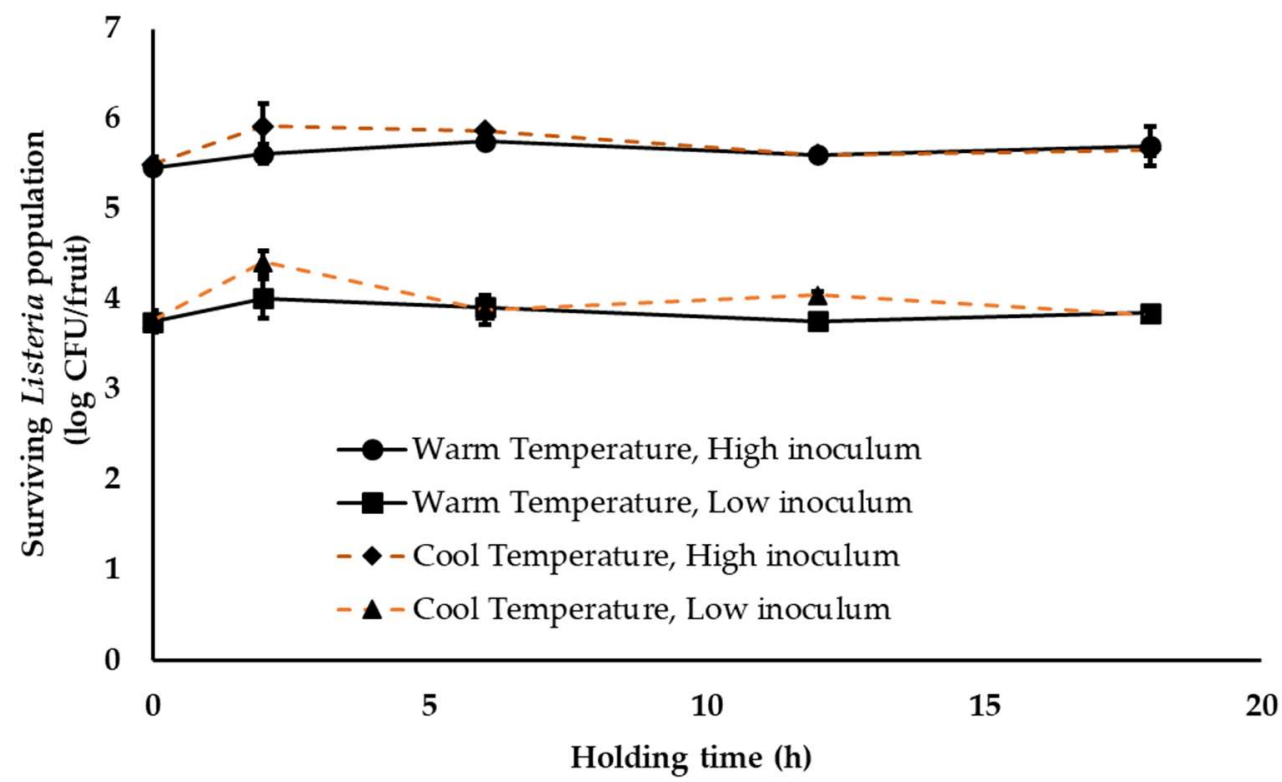

Figure 1. Listeria survival on peaches under simulated stone-fruit packinghouse unloading and staging conditions (temperature- $18-20$ or $28-30{ }^{\circ} \mathrm{C}$ (ambient cool and warm season temperature), $\mathrm{RH}-40-50 \%$ (ambient humidity) and holding time -1 to $18 \mathrm{~h}$ ) at high ( $\sim 5 \log \mathrm{CFU} /$ fruit) and low ( $\sim 3 \log \mathrm{CFU} /$ fruit) pathogen load. Data are represented as the mean \pm SE.

\subsection{Effect of Fruit Waxing and Fungicide Application on Listeria Survival on Stone Fruits}

One of the common practices at a stone-fruit packinghouse is application of fruit finish containing fungicides. This is generally applied once staged fruit are transferred to the packing line [37]. In order to simulate this waxing and fungicide application at the stone-fruit packinghouse, two commonly used fruit finish namely PF220 (mineral-oilbased, M) and PF55EU (vegetable-oil-based, V) were employed in combination with two widely used fungicides, propiconazole (Mentor ${ }^{\circledR} ;$ P) and fludioxonil (PacRite ${ }^{\circledR}$ FDL; F). Following waxing, fruit are graded, sized, packed and moved to the cooling room. The average time between packing and cooling is generally about $4-6 \mathrm{~h}$. During this time, fruits are held under ambient conditions. Hence, in this study, waxed fruit were packed in containers and held under ambient conditions for $6 \mathrm{~h}$. Irrespective of the type of wax and fungicide applied, Listeria was able to survive in significant numbers on peaches (Figures 2 and 3). At high inoculum levels and under cool ambient conditions, 5.3 \pm 0.14 , $5.52 \pm 0.1,5.41 \pm 0.1,5.3 \pm 0.1$ and $5.40 \pm 0.05,5.44 \pm 0.13,5.59 \pm 0.1$ and $5.50 \pm 0.12$ $\log$ CFU of Listeria was recovered at 0 and $6 \mathrm{~h}$ from fruits treated with MP, VP, MF and VF, respectively (Figure 2). Further, no significant change in pathogen population was observed throughout the $6 \mathrm{~h}$ holding period. Similarly, at low inoculum levels, $\sim 3.51 \pm 0.09$ and $3.45 \pm 0.05 \log$ CFU of Listeria/peach was recovered across different treatments at 0 and $6 \mathrm{~h}$, respectively. Additionally, no significant reduction in pathogen population was observed on waxed fruits held under warm ambient conditions (Figure 3). Similar results were obtained with experiments performed on nectarines. As previously observed, regardless of the inoculation levels, stone-fruit waxing and fungicide application under ambient warm and cool temperatures did not favor Listeria growth, as evidenced from the absence of significant increase in pathogen population over time. 


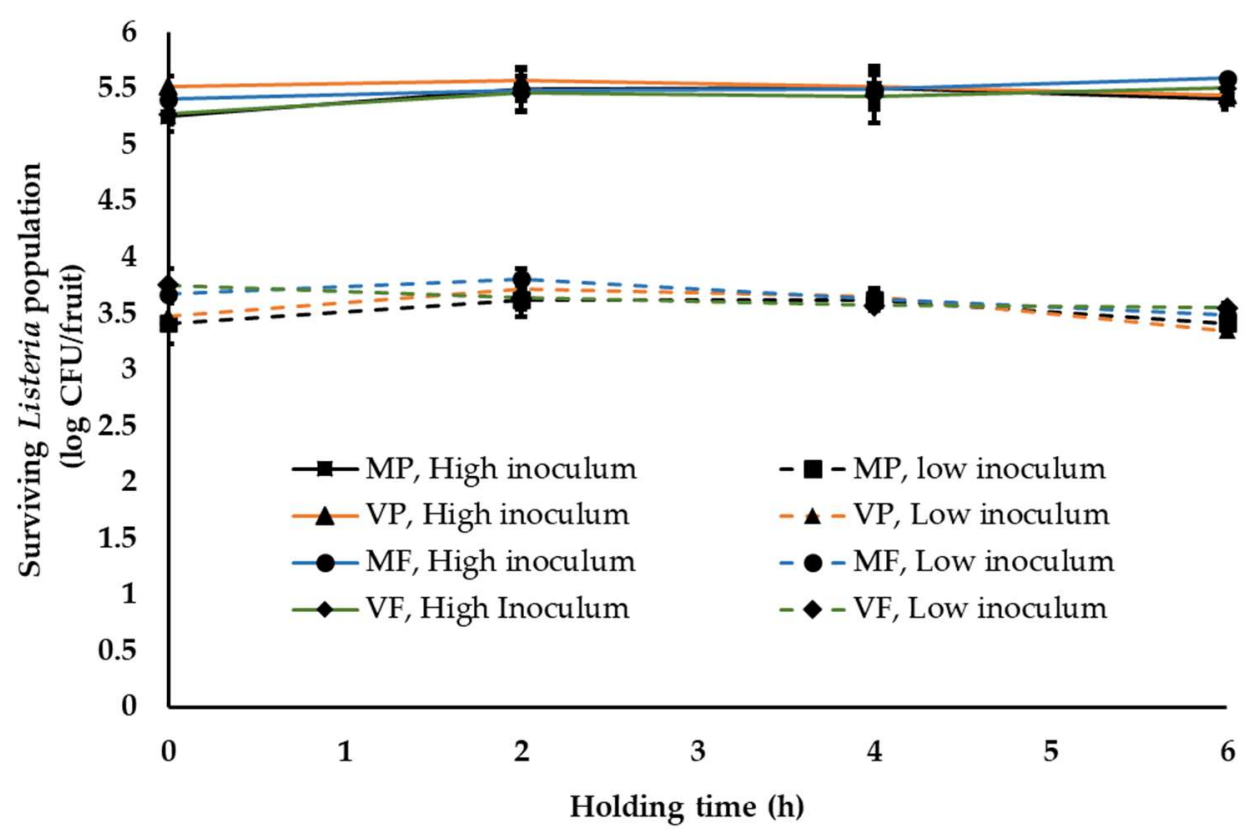

Figure 2. Listeria survival on peaches following fruit waxing and fungicide application under simulated packinghouse conditions (temperature $-18-20^{\circ} \mathrm{C}$ (ambient cool temperature), $\mathrm{RH}-40-50 \%$ (ambient humidity) and holding time-1 to $6 \mathrm{~h})$ at high $(\sim 5 \log \mathrm{CFU} /$ fruit) and low ( 3 log CFU/fruit) pathogen load. Fruit finish formulations used in the study include MP, mineral oil + propiconazole; VP, vegetable oil + propiconazole; MF, mineral oil + fludioxonil; and VF, vegetable oil + fludioxonil. Data are represented as the mean \pm SE.

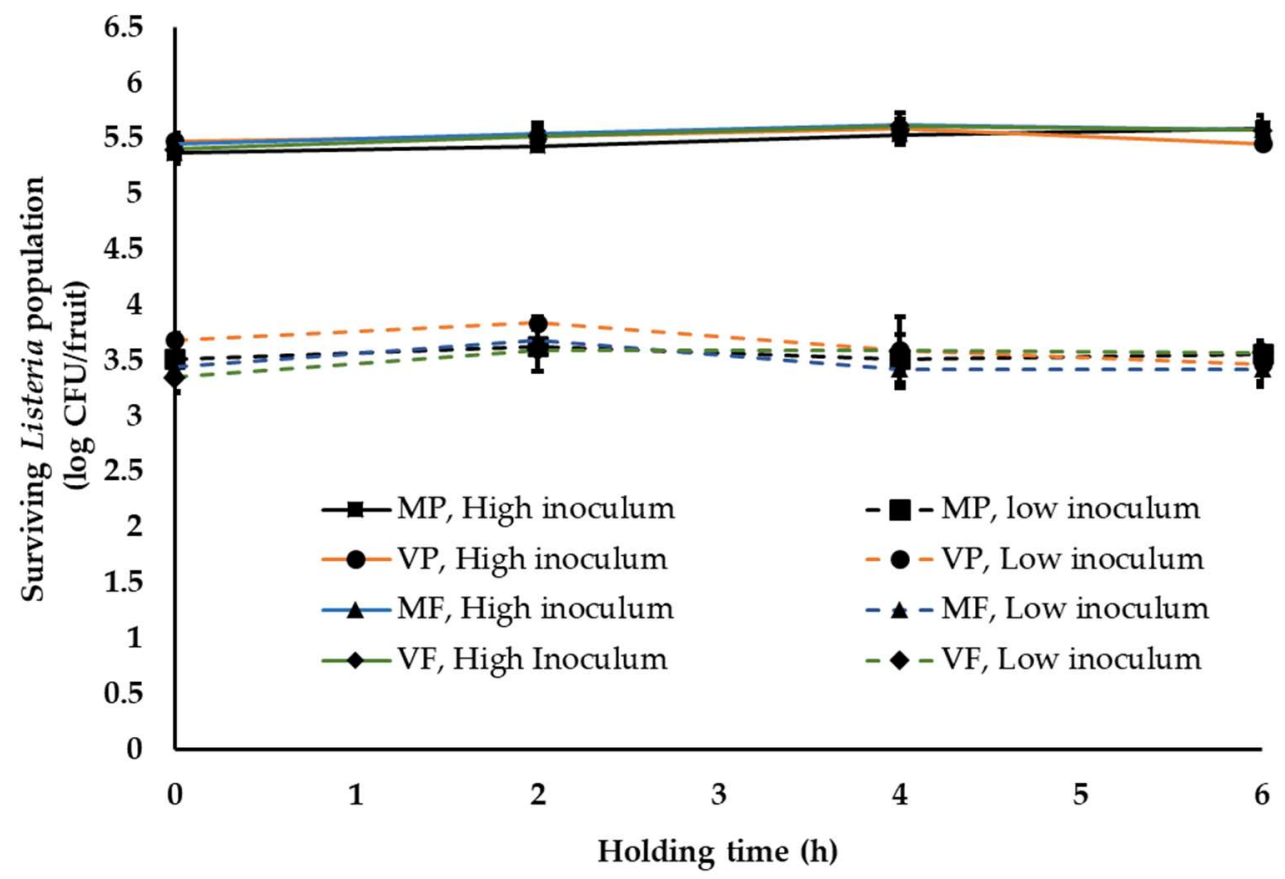

Figure 3. Listeria survival on peaches following fruit waxing and fungicide application under simulated packinghouse conditions (temperature-28-30 ${ }^{\circ} \mathrm{C}$ (ambient warm season temperature), $\mathrm{RH}-40-50 \%$ (ambient humidity) and holding time -1 to $6 \mathrm{~h})$ at high $(\sim 5 \log \mathrm{CFU} /$ fruit) and low ( 3 log CFU/fruit) pathogen load. Fruit finish formulations used in the study include MP, mineral oil + propiconazole; VP, vegetable oil + propiconazole; MF, mineral oil + fludioxonil; and VF, vegetable oil + fludioxonil. Data are represented as the mean $\pm \mathrm{SE}$. 


\subsection{Effect of Refrigerated Storage Conditions on Listeria Survival on Waxed Stone Fruits}

The final storage temperature and high humidity is particularly critical for peach and nectarines since they are highly perishable and deteriorate quickly at ambient temperatures [56,57]. Therefore, waxed fruit are held in cold storage for $2-28$ days at $1-2{ }^{\circ} \mathrm{C}$ and RH-90-95\% before being shipped to market in refrigerated trailers. Since we did not observe any significant difference in Listeria population on waxed fruits held at ambient warm and cool temperatures, fruits were waxed and packed under warm ambient conditions prior to refrigerated storage. Over the four-week storage period, irrespective of the inoculum load and wax/fungicide treatment, no significant reduction in Listeria population was observed on both peaches and nectarines. At the end of storage (4 weeks) approximately 5.3-5.5 and 3.5-3.6 log CFU of Listeria was recovered from peaches and nectarines at high and low inoculum level, respectively (Figure 4). This indicates that although low temperature may deter pathogen growth it does not inhibit Listeria survival on peaches and nectarines. Overall, ambient conditions and practices simulating the packing-house were not found to significantly deter Listeria survival on peaches and nectarines.

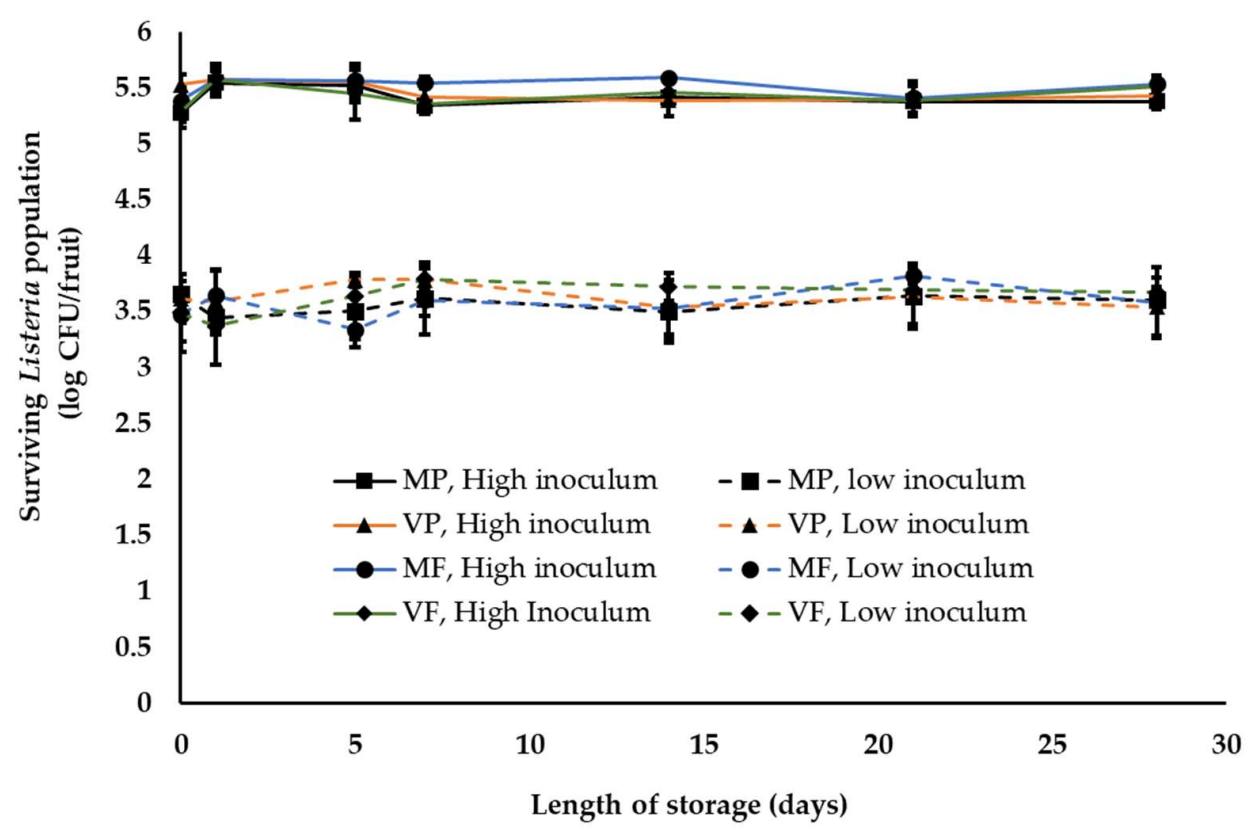

Figure 4. Listeria survival on peaches following fruit waxing and fungicide application and refrigerated storage under simulated packinghouse conditions (temperature- $1-2{ }^{\circ} \mathrm{C}, \mathrm{RH}-85-95 \%$ (ambient humidity) and length of storage- 3 to 4 weeks) at high ( $\sim 5 \log \mathrm{CFU} /$ fruit) and low ( 3 $\log \mathrm{CFU} /$ fruit) pathogen load. Fruit finish formulations used in the study include MP, mineral oil + propiconazole; VP, vegetable oil + propiconazole; MF, mineral oil + fludioxonil; and VF, vegetable oil + fludioxonil. Data are represented as the mean \pm SE.

\section{Discussion}

Scenario analyses conducted by the FDA-CFSAN (Center for Food Safety and Nutrition) and USDA-FSIS (Food Safety and Inspection Service) demonstrated that risk for listeriosis from a given food was primarily governed by the food's composition and its handling and storage conditions [58,59]. All of these factors are highly relevant to fresh produce and its processing environment. Further, the absence of practical technologies that provide a necessary kill step for pathogens on fresh produce, including peaches and nectarines, provides a unique challenge to the stone-fruit industry. Additionally, recall of stone fruits due to potential Listeria contamination has highlighted the need for generation of risk reduction knowledge towards the development of preventive controls for foodborne pathogens. In order to develop preventive controls, it is critical to understand the effect of stone-fruit processing conditions on pathogen survival. Hence, this study was performed 
to determine the influence of commercial packinghouse conditions and practices on Listeria survival on stone fruits.

In addition to the ambient environment, the inherent nature of the produce, including the surface structure and topographic characteristics, can influence pathogen attachment, survival and growth [32]. Therefore, to account for differences in produce type, Listeria survival was assessed on peaches and nectarines. Peaches in general have a downy or fuzzy surface while nectarines have smooth skins [60]. Nectarines arose as peach mutants, with differences in fruit size, shape, firmness, external color, aroma, flavor and disease resistance and better storage characteristics than peaches [61,62]. Given the topographical differences, Collignon and Korsten [8] studied pathogen attachment and survival as influenced by produce type. They demonstrated that survival and recovery of pathogens differed with different fruits. For instance, Listeria was found to survive better on peaches than on plums. Contrary to these results, De Jesus et al. [15] reported that stone-fruit type did not affect Listeria survival under refrigerated storage $\left(4^{\circ} \mathrm{C}, 90-92 \% \mathrm{RH}\right)$ for 26 days. Similarly, we did not observe any significant difference in Listeria survival on yellow flesh peaches (var. Autumn Flame) and nectarines (var. August Fire; Figures 1-4). Survival patterns of Listeria at both high and low inoculum did not show any significant differences between peaches and nectarines. This is in agreement with reports on the growth and survival of $L$ monocytogenes in raw fruits and vegetables with varying surface characteristics [63-66].

In addition to the above factors, pathogen type also influences its survival on produce. Studies investigating Salmonella, E. coli O157 and Listeria survival on produce have demonstrated a difference in growth and survivability of the pathogens [67]. Different studies have demonstrated a longer persistence of Listeria on fresh produce at refrigeration temperatures when compared to the other pathogens $[20,48,67]$. Hence proper temperature regulation and monitoring is of particular significance in the control of Listeria. Several studies have investigated the persistence of Listeria on different produce, including tomatoes, asparagus, stone fruits, apples, strawberries and surface of fruits with inedible skin, such as bananas and watermelons, under simulated processing, storage and distribution conditions $[8,34,50,68-70]$. These studies demonstrated that Listeria could survive on fruit surface for extended periods of time, under different storage temperatures, including ambient temperature $\left(21^{\circ} \mathrm{C}\right)$, cold storage at 10 or $4{ }^{\circ} \mathrm{C}$ and freezing at $-20^{\circ} \mathrm{C}[8,34,67]$. In particular, Collignon and Korsten [8] observed a significant reduction in Listeria populations on peaches and plums during the initial days of storage under simulated commercial export chain conditions. However, in the present study we did not observe any significant reduction in pathogen population across all storage conditions (Figures 1-4). This could be due to differences in temperature-relative humidity and length of storage conditions employed in the present study.

Relative humidity also significantly influences pathogen survival on fruits. Likotrafiti et al. [35] demonstrated that Listeria survival on fresh lettuce and cucumber was unaffected by change in relative humidity $(\mathrm{RH})$. Equal populations of Listeria were recovered from produce maintained at an $\mathrm{RH}$ of 55 or $90 \%$. However, Listeria growth was found to be slower at lower RH. Similar study performed by Palumbo and Williams [71] evaluating Listeria survival in different menstrua demonstrated that reduced growth rate at lower RH (59\%) was associated with prolonged survival and recovery of Listeria. The results from these studies highlight the unique ability of Listeria to survive and withstand reduced $\mathrm{RH}$ or dry conditions that are commonly encountered on produce surface. This finding is in agreement with our study where warm summer temperature of 28 to $30{ }^{\circ} \mathrm{C}$ and ambient cool temperature of 18 to $20^{\circ} \mathrm{C}$ and $40-50 \% \mathrm{RH}$, did not have any significant reduction on the inoculated Listeria population, both at high and low inoculum (Figures 13). Similarly, fruit storage under conditions of high relative humidity (85-95\%) also did not affect pathogen survival (Figure 4). Hence, irrespective of the ambient relative humidity, Listeria was able to survive in significant numbers on stone fruits. However, although these conditions supported Listeria survival, they did not promote pathogen growth on the produce. 
Besides the ambient conditions associated with stone-fruit processing, fruit waxing and fungicide application are an integral part of the packinghouse practices. In the case of stone fruits, besides helping to reduce moisture loss, fruit finish is used as a carrier for fungicides $[37,72,73]$. Commercial fruit finish widely employed in the industry are either mineral or vegetable oil based. In addition to waxing, stone fruits are treated with fungicides for post-harvest control of brown rot and sour rot [40]. The commonly used fungicides in the stone-fruit industry include propiconazole and fludioxonil. Hence to simulate industry practices, a combination of fruit finish and fungicides were employed in this study. As with other practices, wax treatments could influence pathogen survival by providing limited dehydration protection to the microbe and thereby favoring bacterial survival [39]. Similarly, several studies have demonstrated the effect of fungicide application on bacteria survival. Sethi et al. [41] observed that fungicide application enhanced the growth of E. coli, Bacillus subtilis, Serratia marcescens and Enterobacter. Further studies demonstrated that different fungicides exert differential effects on bacterial survival. Yen et al. [42] demonstrated that the application of propiconazole inhibited microbial population, while triadimefon induced bacterial survival. This variation in effect could be explained by the difference in mode of action of the fungicides [43]. These studies indicate that post-harvest practices, including the application of fruit finish and fungicide, can influence Listeria survival and growth on fruit surface. Along the same lines, Kenney and Beuchat [73] evaluated the effect of six different wax formulations, including Carnauba Gold, on Salmonella Muenchen survival on apples. They observed that waxing by itself did not result in any significant reduction in Salmonella populations on apples. Further, our previous study evaluating Salmonella survival on mangoes did not observe any effect of waxing on pathogen survival [46]. Similarly, in the present study, Listeria survival was unaffected by the inoculum level, the type of wax and fungicide used and holding/storage time (Figures 2-4). More specifically, no significant reduction in pathogen population was observed under conditions simulating commercial stone-fruit handling and storage.

\section{Conclusions}

The results of our study demonstrate that current stone-fruit handling conditions do not favor Listeria growth. However, once contaminated, Listeria can survive on the fruit surface in significant numbers under current packinghouse conditions and practices. Further, commercial waxes and fungicides employed in the stone-fruit industry did not exhibit any inhibitory effect on pathogen survival. Therefore, once contaminated, fruit can serve as a potential source for Listeria transmission along the post-harvest environment. In conclusion, these results demonstrate the need for development and implementation of preventive controls at the stone-fruit packinghouse to prevent Listeria contamination and deter pathogen persistence.

Author Contributions: M.A.A. conceived and designed the experiments; D.K., M.S.M. and E.M. performed the experiments; M.S.M. analyzed the data; D.K. wrote sections of the manuscript; M.A.A. wrote and revised the paper. All authors have read and agreed to the published version of the manuscript.

Funding: This research was funded by Center for Produce Safety (CPS) and California Department of Food and Agriculture (CDFA; Specialty Crop Block Grant Program) under award \#2017CPS02. Any opinions, findings, conclusions and recommendations expressed in this manuscript are those of the authors and do not necessarily reflect the views of CPS or CDFA.

Institutional Review Board Statement: Not applicable.

Informed Consent Statement: Not applicable.

Data Availability Statement: Data from this study were submitted as project results and performance reports to CPS and can be accessed at https:/ / www.centerforproducesafety.org/amass/documents/ researchproject/403/CPS\%20Final\%20Report_Amalaradjou\%2C\%20January\%202018.pdf (accessed on 8 August 2021). 
Acknowledgments: The authors would like to thank George Nikolich (Former Vice President, Technical Operations, Prima ${ }^{\circledR}$ Wawona; Current President, George Nikolich Consulting, Inc.) for providing valuable insights into stone-fruit packinghouse operations and Prima ${ }^{\circledR}$ Wawona for supplying peaches and nectarines for use in this study. We also thank Michelle Smith, Pace International, for providing us with the fungicides and wax coatings used in the study.

Conflicts of Interest: The authors declare no conflict of interest.

\section{References}

1. Balali, G.I.; Yar, D.D.; Afua Dela, V.G.; Adjei-Kusi, P. Microbial Contamination, an Increasing Threat to the Consumption of Fresh Fruits and Vegetables in Today's World. Int. J. Microbiol. 2020, 2020, 3029295. [CrossRef] [PubMed]

2. Luo, Y.; Nou, X.; Millner, P.; Zhou, B.; Shen, C.; Yang, Y.; Wu, Y.; Wang, Q.; Feng, H.; Shelton, D. A Pilot Plant Scale Evaluation of a New Process Aid for Enhancing Chlorine Efficacy Against Pathogen Survival and Cross-Contamination during Produce Wash. Int. J. Food Microbiol. 2012, 158, 133-139. [CrossRef] [PubMed]

3. Carstens, C.K.; Salazar, J.K.; Darkoh, C. Multistate Outbreaks of Foodborne Illness in the United States Associated with Fresh Produce from 2010 to 2017. Front. Microbiol. 2019, 10, 2667. [CrossRef]

4. Callejon, R.M.; Rodriguez-Naranjo, M.I.; Ubeda, C.; Hornedo-Ortega, R.; Garcia-Parrilla, M.C.; Troncoso, A.M. Reported Foodborne Outbreaks due to Fresh Produce in the United States and European Union: Trends and Causes. Foodborne Pathog. Dis. 2015, 12, 32-38. [CrossRef]

5. McDaniel, C.; Jadeja, R. A Review of Fresh Produce Outbreaks, Current Interventions, Food Safety Concerns and Potential Benefits of Novel Antimicrobial Sodium Acid Sulfate. MOJ Food Process. Technol. 2019, 7, 59-67.

6. Johnson, R. Foodborne Illnesses and Outbreaks from Fresh Produce; Congressional Research Service: Washington, DC, USA, 2019. Available online: https:/ / fas.org/sgp/crs/misc/IF11092.pdf (accessed on 3 August 2021).

7. Buchanan, R.L.; Gorris, L.G.; Hayman, M.M.; Jackson, T.C.; Whiting, R.C. A Review of Listeria monocytogenes: An Update on Outbreaks, Virulence, Dose-Response, Ecology, and Risk Assessments. Food Control 2017, 75, 1-13. [CrossRef]

8. Collignon, S.; Korsten, L. Attachment and Colonization by Escherichia coli O157:H7, Listeria monocytogenes, Salmonella enterica Subsp. enterica Serovar Typhimurium, and Staphylococcus aureus on Stone Fruit Surfaces and Survival through a Simulated Commercial Export Chain. J. Food Prot. 2010, 73, 1247-1256.

9. US Food and Drug Administration. Jac. Vandenberg, Inc. Recalls Fresh Peaches, Fresh Nectarines and Fresh Plums because They May Be Contaminated with Listeria monocytogenes. 2019. Available online: https://www.fda.gov/safety/recalls-marketwithdrawals-safety-alerts/jac-vandenberg-inc-recalls-fresh-peaches-fresh-nectarines-and-fresh-plums-because-they-may-be (accessed on 3 August 2021).

10. Jackson, B.R.; Salter, M.; Tarr, C.; Conrad, A.; Harvey, E.; Steinbock, L.; Saupe, A.; Sorenson, A.; Katz, L.; Stroika, S.; et al. Notes from the Field: Listeriosis Associated with Stone Fruit-United States, 2014. MMWR Morb. Mortal. Wkly. Rep. 2015, 64, $282-283$.

11. McCollum, J.T.; Cronquist, A.B.; Silk, B.J.; Jackson, K.A.; O'Connor, K.A.; Cosgrove, S.; Cosgrove, S.; Gossack, J.P.; Parachini, S.S.; Jain, N.S.; et al. Multistate Outbreak of Listeriosis Associated with Cantaloupe. N. Engl. J. Med. 2013, 369, 944-953. [CrossRef]

12. Self, J.L.; Conrad, A.; Stroika, S.; Jackson, A.; Burnworth, L.; Beal, J.; Wellman, A.; Jackson, K.A.; Bidol, S.; Gerhardt, T.; et al. Outbreak of Listeriosis Associated with Consumption of Packaged Salad-United States and Canada, 2015-2016. MMWR Morb. Mortal. Wkly. Rep. 2016, 65, 879-881. [CrossRef] [PubMed]

13. Duvenage, S.; Korsten, L. Assessment of Foodborne Pathogen Presence in the Peach Supply Chain and its Potential Risk to the End Consumer. Food Control 2017, 78, 374-382. [CrossRef]

14. Chen, Y.; Burall, L.S.; Luo, Y.; Timme, R.; Melka, D.; Muruvanda, T.; Payne, J.; Wang, C.; Kastanis, G.; Maounounen-Laasri, A.; et al. Listeria monocytogenes in Stone Fruits Linked to a Multistate Outbreak: Enumeration of Cells and Whole-Genome Sequencing. Appl. Environ. Microbiol. 2016, 82, 7030-7040. [CrossRef] [PubMed]

15. De Jesus, A.J.; Sheth, I.; Kwon, H.J.; Gao, Z.; Palmer, J.; Hur, M.; Hammack, T.S.; Macarisin, D.; Chen, Y. Survival of a Serotype 4b Strain and a Serotype 1/2a Strain of Listeria monocytogenes, Isolated from a Stone Fruit Outbreak Investigation, on Whole Stone Fruit at $4{ }^{\circ}$ C. Int. J. Food Microbiol. 2020, 334, 108801. [CrossRef]

16. Fatica, M.K.; Schneider, K.R. Salmonella and Produce: Survival in the Plant Environment and Implications in Food Safety. Virulence 2011, 2, 573-579. [CrossRef] [PubMed]

17. Huff, K.; Boyer, R.; Denbow, C.; O'Keefe, S.; Williams, R. Effect of Storage Temperature on Survival and Growth of Foodborne Pathogens on Whole, Damaged, and Internally Inoculated Jalapenos (Capsicum annuum Var. Annuum). J. Food Prot. 2012, 75, 382-388. [CrossRef]

18. Welshimer, H.J. Isolation of Listeria monocytogenes from Vegetation. J. Bacteriol. 1968, 95, 300-303. [CrossRef]

19. Locatelli, A.; Spor, A.; Jolivet, C.; Piveteau, P.; Hartmann, A. Biotic and Abiotic Soil Properties Influence Survival of Listeria monocytogenes in Soil. PLoS ONE 2013, 8, e75969.

20. Ukuku, D.O.; Olanya, M.; Geveke, D.J.; Sommers, C.H. Effect of Native Microflora, Waiting Period, and Storage Temperature on Listeria monocytogenes Serovars Transferred from Cantaloupe Rind to Fresh-Cut Pieces during Preparation. J. Food Prot. 2012, 75, 1912-1919. [CrossRef]

21. Farber, J.M.; Peterkin, P.I. Listeria monocytogenes, a Food-Borne Pathogen. Microbiol. Rev. 1991, 55, 476-511. [CrossRef]

22. Brackett, R. Presence and Persistence of Listeria monocytogenes in Food and Water. Food Technol. 1988, 42, $162-164$. 
23. Hellström, S.; Kiviniemi, K.; Autio, T.; Korkeala, H. Listeria monocytogenes is Common in Wild Birds in Helsinki Region and Genotypes are Frequently Similar with those Found Along the Food Chain. J. Appl. Microbiol. 2008, 104, 883-888. [CrossRef] [PubMed]

24. Hellström, S. Contamination Routes and Control of Listeria monocytogenes in Food Production. Ph.D. Thesis, University of Helsinki, Faculty of Veterinary Medicine, Helsinki, Finland, 2011.

25. Kilonzo, C.; Li, X.; Vivas, E.J.; Jay-Russell, M.T.; Fernandez, K.L.; Atwill, E.R. Fecal Shedding of Zoonotic Food-Borne Pathogens by Wild Rodents in a Major Agricultural Region of the Central California Coast. Appl. Environ. Microbiol. 2013, 79, 6337-6344. [CrossRef] [PubMed]

26. Beuchat, L.R. Ecological Factors Influencing Survival and Growth of Human Pathogens on Raw Fruits and Vegetables. Microbes Infect. 2002, 4, 413-423. [CrossRef]

27. Tauxe, R.; Kruse, H.; Hedberg, C.; Potter, M.; Madden, J.; Wachsmuth, K. Microbial Hazards and Emerging Issues Associated with Produce (Dagger) A Preliminary Report to the National Advisory Committee on Microbiologic Criteria for Foods. J. Food Prot. 1997, 60, 1400-1408. [CrossRef] [PubMed]

28. Leong, D.; Alvarez-Ordonez, A.; Jordan, K. Monitoring Occurrence and Persistence of Listeria monocytogenes in Foods and Food Processing Environments in the Republic of Ireland. Front. Microbiol. 2014, 5, 436. [CrossRef]

29. Warriner, K.; Huber, A.; Namvar, A.; Fan, W.; Dunfield, K. Recent Advances in the Microbial Safety of Fresh Fruits and Vegetables. In Advances in Food and Nutrition Research; Taylor, S.L., Ed.; Elsevier: Amsterdam, The Netherlands, 2009; Volume 57, pp. 155-208.

30. Strawn, L.K.; Schneider, K.R.; Danyluk, M.D. Microbial Safety of Tropical Fruits. Crit. Rev. Food Sci. Nutr. 2011, 51, 132-145. [CrossRef]

31. Goodburn, C.; Wallace, C.A. The Microbiological Efficacy of Decontamination Methodologies for Fresh Produce: A Review. Food Control 2013, 32, 418-427. [CrossRef]

32. Marik, C.M.; Zuchel, J.; Schaffner, D.W.; Strawn, L.K. Growth and Survival of Listeria monocytogenes on Intact Fruit and Vegetable Surfaces during Postharvest Handling: A Systematic Literature Review. J. Food Prot. 2020, 83, 108-128. [CrossRef]

33. Amalaradjou, M.A. Listeria monocytogenes Growth and Survival on Peaches and Nectarines as Influenced by Stone Fruit Packing House Operations, Storage and Transportation Conditions. Center for Produce Safety. 2018. Available online: https:/ / www.centerforproducesafety.org/amass/documents/researchproject/403/CPS\%20Final\%20Report_Amalaradjou\% 2C\%20January\%202018.pdf (accessed on 3 August 2021).

34. Flessa, S.; Lusk, D.M.; Harris, L.J. Survival of Listeria monocytogenes on Fresh and Frozen Strawberries. Int. J. Food Microbiol. 2005, 101, 255-262. [CrossRef]

35. Likotrafiti, E.; Smirniotis, P.; Nastou, A.; Rhoades, J. Effect of Relative Humidity and Storage Temperature on the Behavior of Listeria monocytogenes on Fresh Vegetables. J. Food Saf. 2013, 33, 545-551. [CrossRef]

36. Salazar, J.K.; Carstens, C.K.; Bathija, V.M.; Narula, S.S.; Parish, M.; Tortorello, M.L. Fate of Listeria monocytogenes in Fresh Apples and Caramel Apples. J. Food Prot. 2016, 79, 696-702. [CrossRef]

37. California Fresh Fruit Association (CFFA). Food Safety Guidelines for Fresh, Whole Stone Fruit Produced in California's San Joaquin Valley; CFFA: Fresno, CA, USA, 2015; pp. 1-49.

38. Francis, G.; Gallone, A.; Nychas, G.; Sofos, J.; Colelli, G.; Amodio, M.; Spano, G. Factors Affecting Quality and Safety of Fresh-Cut Produce. Crit. Rev. Food Sci. Nutr. 2012, 52, 595-610. [CrossRef]

39. Cifuentes, R.A.; Hernandez, A.M.; Harris, L.J.; Suslow, T.V. Assessment of Production and Retail Handling Practices of Peaches, Plums and Nectarines on Microbial Food Safety Risk Reduction. Hortscience 2001, 36, 544-545.

40. Adaskaveg, J.; Förster, H. Management of Gray Mold of Pomegranates Caused by Botrytis cinerea using Two Reduced-Risk Fungicides, Fludioxonil and Fenhexamid. Phytopathology 2003, 93, S127.

41. Sethi, S.; Pophle, S.; Varte, N.; Salve, C.; Waghela, S. Microbial Population Response Exposed to Different Pesticides. Int. J. Sci. Eng. Appl. Sci. 2015, 1, 250-255.

42. Yen, J.; Chang, J.; Huang, P.; Wang, Y. Effects of Fungicides Triadimefon and Propiconazole on Soil Bacterial Communities. J. Environ. Sci. Health B 2009, 44, 681-689. [CrossRef] [PubMed]

43. Yang, C.; Hamel, C.; Vujanovic, V.; Gan, Y. Fungicide: Modes of Action and Possible Impact on Non-Target Microorganisms. ISRN Ecol. 2011, 2011, 130289.

44. Hoelzer, K.; Pouillot, R.; Dennis, S. Listeria monocytogenes Growth Dynamics on Produce: A Review of the Available Data for Predictive Modeling. Foodborne Pathog. Dis. 2012, 9, 661-673. [CrossRef]

45. Penteado, A.L.; Eblen, B.S.; Miller, A.J. Evidence of Salmonella Internalization into Fresh Mangos during Simulated Postharvest Insect Disinfestation Procedures. J. Food Prot. 2004, 67, 181-184. [CrossRef]

46. Mathew, E.N.; Muyyarikkandy, M.S.; Kuttappan, D.; Amalaradjou, M.A. Attachment of Salmonella enterica on Mangoes and Survival Under Conditions Simulating Commercial Mango Packing House and Importer Facility. Front. Microbiol. 2018,9 , 1519. [CrossRef]

47. Parnell, T.L.; Harris, L.J.; Suslow, T.V. Reducing Salmonella on Cantaloupes and Honeydew Melons using Wash Practices Applicable to Postharvest Handling, Foodservice, and Consumer Preparation. Int. J. Food Microbiol. 2005, 99, 59-70. [CrossRef] [PubMed]

48. Danyluk, M.D.; Friedrich, L.M.; Schaffner, D.W. Modeling the Growth of Listeria monocytogenes on Cut Cantaloupe, Honeydew and Watermelon. Food Microbiol. 2014, 38, 52-55. [CrossRef] [PubMed] 
49. Beuchat, L.R.; Farber, J.M.; Garrett, E.H.; Harris, L.J.; Parish, M.E.; Suslow, T.V.; Busta, F.F. Standardization of a Method to Determine the Efficacy of Sanitizers in Inactivating Human Pathogenic Microorganisms on Raw Fruits and Vegetables. J. Food Prot. 2001, 64, 1079-1084. [CrossRef] [PubMed]

50. Behrsing, J.; Jaeger, J.; Horlock, F.; Kita, N.; Franz, P.; Premier, R. Survival of Listeria innocua, Salmonella Salford and Escherichia coli on the Surface of Fruit with Inedible Skins. Postharvest Biol. Technol. 2003, 29, 249-256. [CrossRef]

51. Baskaran, S.A.; Upadhyay, A.; Kollanoor-Johny, A.; Upadhyaya, I.; Mooyottu, S.; Roshni Amalaradjou, M.A.; Schreiber, D.; Venkitanarayanan, K. Efficacy of Plant-Derived Antimicrobials as Antimicrobial Wash Treatments for Reducing Enterohemorrhagic Escherichia coli O157:H7 on Apples. J. Food Sci. 2013, 78, M1399-M1404. [CrossRef]

52. Parnell, T.L.; Harris, L.J. Reducing Salmonella on Apples with Wash Practices Commonly used by Consumers. J. Food Prot. 2003, 66, 741-747. [CrossRef]

53. Sheng, L.; Edwards, K.; Tsai, H.C.; Hanrahan, I.; Zhu, M.J. Fate of Listeria monocytogenes on Fresh Apples Under Different Storage Temperatures. Front. Microbiol. 2017, 8, 1396. [CrossRef]

54. Lovett, J.; Hitchins, A.D. Listeria isolation. In Bacteriological Analytical Manual, 6th ed.; U.S. Food and Drug Administration: Silver Spring, MD, USA, 1988; Volume 53, pp. 44148-44153.

55. Lang, M.M.; Harris, L.J.; Beuchat, L.R. Evaluation of Inoculation Method and Inoculum Drying Time for their Effects on Survival and Efficiency of Recovery of Escherichia coli O157:H7, Salmonella, and Listeria monocytogenes Inoculated on the Surface of Tomatoes. J. Food Prot. 2004, 67, 732-741. [CrossRef]

56. Cano-Salazar, J.; López, L.; Crisosto, C.H.; Echeverría, G. Cold Storage of Six Nectarine Cultivars: Consequences for Volatile Compounds Emissions, Physicochemical Parameters, and Consumer Acceptance. Eur. Food Res. Technol. 2013, 237, 571-589. [CrossRef]

57. Dagar, A.; Weksler, A.; Friedman, H.; Ogundiwin, E.A.; Crisosto, C.H.; Ahmad, R.; Lurie, S. Comparing Ripening and Storage Characteristics of 'Oded'peach and its Nectarine Mutant 'Yuval'. Postharvest Biol. Technol. 2011, 60, 1-6. [CrossRef]

58. Luber, P. The Codex Alimentarius Guidelines on the Application of General Principles of Food Hygiene to the Control of Listeria monocytogenes in Ready-To-Eat Foods. Food Control 2011, 22, 1482-1483. [CrossRef]

59. US Food and Drug Administration; US Department of Agriculture, Food Safety and Inspection Service. Quantitative Assessment of Relative Risk to Public Health from Foodborne Listeria monocytogenes among Selected Categories of Ready-to-Eat Foods; Center of Food Safety and Applied Nutrition, Food and Drug Administration, U.S. Department of Health and Human Services and the Food Safety and Inspection Services, U.S. Department of Agriculture: Washington, DC, USA, 2003. Available online: https:/ / www.fda.gov / media/124721/download (accessed on 4 August 2021).

60. Layne, D.R.; Bassi, D. The Peach: Botany, Production and Uses; CABI: Cambridge, MA, USA, 2008; pp. 1-36.

61. Crisosto, C.H.; Mitchell, F.G.; Ju, Z. Susceptibility to Chilling Injury of Peach, Nectarine, and Plum Cultivars Grown in California. Hortic. Sci. 1999, 34, 1116-1118. [CrossRef]

62. Wen, I.; Koch, K.; Sherman, W. Comparing Fruit and Tree Characteristics of Two Peaches and Their Nectarine Mutants. J. Am. Soc. Hortic. Sci. 1995, 120, 101-106. [CrossRef]

63. De Oliveira, M.A.; Ribeiro, E.G.A.; Bergamini, A.M.M.; De Martinis, E.C.P. Quantification of Listeria monocytogenes in Minimally Processed Leafy Vegetables Using a Combined Method Based on Enrichment and 16S rRNA Real-Time PCR. Food Microbiol. 2010, 27, 19-23. [CrossRef] [PubMed]

64. Sant'Ana, A.S.; Barbosa, M.S.; Destro, M.T.; Landgraf, M.; Franco, B.D. Growth Potential of Salmonella Spp. and Listeria monocytogenes in Nine Types of Ready-to-Eat Vegetables Stored at Variable Temperature Conditions during Shelf-Life. Int. J. Food Microbiol. 2012, 157, 52-58. [CrossRef] [PubMed]

65. Wu, S.; Wu, Q.; Zhang, J.; Chen, M.; Yan, Z.A.; Hu, H. Listeria monocytogenes Prevalence and Characteristics in Retail Raw Foods in China. PLOS ONE 2015, 10, e0136682.

66. Zhu, Q.; Gooneratne, R.; Hussain, M.A. Listeria monocytogenes in Fresh Produce: Outbreaks, Prevalence and Contamination Levels. Foods 2017, 6, 21. [CrossRef]

67. Alegre, I.; Abadias, M.; Anguera, M.; Usall, J.; Vinas, I. Fate of Escherichia coli O157:H7, Salmonella and Listeria innocua on Minimally-Processed Peaches Under Different Storage Conditions. Food Microbiol. 2010, 27, 862-868. [CrossRef] [PubMed]

68. Beuchat, L.R.; Brackett, R.E. Behavior of Listeria monocytogenes Inoculated into Raw Tomatoes and Processed Tomato Products. Appl. Environ. Microbiol. 1991, 57, 1367-1371. [CrossRef]

69. Rodríguez, A.C.; Alcalá, E.B.; Gimeno, R.G.; Cosano, G.Z. Growth Modelling of Listeria monocytogenes in Packaged Fresh Green Asparagus. Food Microbiol. 2000, 17, 421-427. [CrossRef]

70. Conway, W.S.; Leverentz, B.; Saftner, R.A.; Janisiewicz, W.J.; Sams, C.E.; Leblanc, E. Survival and Growth of Listeria monocytogenes on Fresh-Cut Apple Slices and its Interaction with Glomerella cingulata and Penicillium expansum. Plant Dis. 2000, 84, 177-181. [CrossRef] [PubMed]

71. Palumbo, S.A.; Williams, A.C. Effect of Temperature, Relative Humidity, and Suspending Menstrua on the Resistance of Listeria monocytogenes to Drying. J. Food Prot. 1990, 53, 377-381. [CrossRef] [PubMed] 
72. Crisosto, C.H.; Garner, D.; Wiley, N.; Crisosto, G. Evaluation of the Effect of the Brushing and Waxing Operations on Peach and Nectarine Postharvest Performance. In 1992 Research Reports for California Peaches and Nectarines, California Tree Fruit Agreement; University of California: Sacramento, CA, USA, 1992.

73. Kenney, S.J.; Beuchat, L.R. Survival of Escherichia coli O157: H7 and Salmonella Muenchen on Apples as Affected by Application of Commercial Fruit Waxes. Int. J. Food Microbiol. 2002, 77, 223-231. [CrossRef] 